\title{
MEDIA SOSIAL MENJADI ANCAMAN TERHADAP EKSISTENSI KEHARMONISAN RUMAH TANGGA KELUARGA HINDU (KAJIAN ANTROPOLOGI KESEHATAN)
}

\author{
Oleh: I Kadek Sukiada, S.AG.,M.SI
}

\begin{abstract}
ION
Advances in communication technology can provide ease to interact also entertainment through cyberspace. So the limits of mass communication and interpersonal communication become rather pseudo, the emergence of new ways of communicating to society, through social media. The existence of shifting function of the mobile phone, which initially only serves to send a message or call someone has developed far into a 'laptop' that can be easily taken anywhere. Most people prefer to keep a BB pin compared to storing phone numbers. The impact of these developments, so that it needs an increase in public awareness about the surrounding environment, especially families, because unconsciously or consciously has changed the lifestyle of every family in the community.

The family will achieve a degree of harmony if it is not based solely on biological factors, but the aspect of affection must prevail within it as the main pillar of maternal stability. The family organization system must be balanced by maintaining the strap within which is a harmony based on love affair. So with sex, in his view is one of the biological needs of living beings, especially by a two-legged creature, having a nose, a two-handed, walking by standing, having a mind, called a human being.
\end{abstract}

\section{PENDAHULUAN}

Rumah tangga adalah sebuah keluarga, yang anggotanya masingmasing memiliki peran berbeda. Wanita di dalam sebuah keluarga memiliki peran sebagai seorang istri dan pria berperan sebagai seorang suami. Pria dan wanita sejak awal keberadaannya telah tercipta sebagai dua manifestasi kekuatan yang berbeda. Hubungan antara pria dan wanita dalam perspektif agama Hindu yaitu dwaita dan adwaita .

Pasangan suami istri pada awal pernikahannya, agama menjadi benteng diri dan juga termasuk adat istiadatnya. Ketika salah satu seorang suami dan istri dipandang telah keluar dari sebuah kebiasaan, maka akan muncul permasalahan dalam rumah tangganya. Keluarga dalam suatu rumah tangga memiliki kewajiban untuk mencapai tujuan hidup sebagai suami istri yang menjadi pasangannya. Pandangan agama Hindu tentang rumah tangga harmonis telah dipraktekkan dalam ajaran Ithiasa yaitu kisah Ramayana dan Mahabharata. Peran Dewi Sita dan Rama sebagai kisah sepasang suami istri yang ideal dalam kisah Ramayana. Sitarama menjalankan hidup untuk saling menerima dan memberi antara yang satu dengan yang lain. Sita 
berperan sebagai seorang istri yang tauladan, sedangkan Rama berperan sebagai seorang suami. Hubungan harmonis yang dijalin dalam suatu rumah tangga didasari oleh suatu hubungan kasih sayang bukan hubungan saling memusuhi diantaranya.

Pada era ini, terjadi kemajuan dibidang ilmu pengetahuan dan tehknologi sehingga menjadikan kemudahan dalam hal informasi dan komunikasi. Kemudahan tersebut, tanpak pada perkembangan internet yang sangat berpengaruh terhadap kehidupan sosial dan juga cara berkomunikasi seseorang. Perkembangan yang terjadi terhadap telepon genggam juga semakin mempermudah komunikasi melalui sosial media maupun internet. Hanya dari sebuah handphone bisa mendapatkan begitu banyak informasi secara singkat. Handphone canggih dapat berfungsi hampir sama dengan sebuah computer jinjing atau laptop namun berukuran jauh lebih kecil. Kemajuan teknologi memberikan kesempatan untuk hidup secara lebih mudah. Hal tersebut merupakan kemudahan untuk mendapatkan atau juga menyebarkan informasi yang diinginkan. Perkembangan Teknologi Informasi berpengaruh terhadap semua faktor, sehingga memiliki dampak positif maupun negatif dalam kehidupan, terutama dalam kehidupan berumahtangga.

\section{Pembahasan}

\subsection{Dampak Penggunaan Media} Sosial dalam Masyarakat

Era globalisasi memiliki pengaruh yang kuat disegala dimensi dalam kehidupan masyarakat. Sehingga terjadinya perubahan-perubahan sosial baik secara positif maupun negatif. Perkembangan teknologi membuat masyarakat harus menentukan diantara dua pilihan. Disatu pihak masyarakat menerima kehadiran teknologi, dan di pihak lain kehadiran teknologi modern justru menimbulkan masalah-masalah yang bersifat struktural dan kemudian merambah di semua aspek kehidupan masyarakat. Terkait dengan perkembangan teknologi yang berdampak kearah modernisasi, IPTEK merupakan yang paling pesat perkembangannya. Salah satu diantaranya yang cukup membuat masyarakat terkagum-kagum ialah perkembangan teknologi informasi.

Teknologi informasi khususnya sosial media merupakan salah satu bentuk kemajuan informasi dan komunikasi. Sosial media yang semakin banyak berkembang memungkinkan informasi menyebar dengan mudah di masyarakat. Informasi dalam bentuk apapun dapat disebarluaskan dengan $\mathrm{m}$ udah dan cepat sehingga mempengaruhi cara pandang, gaya 
hidup, serta budaya suatu bangsa. Arus informasi yang cepat menyebabkan adanya ketidak-mampuan masyarakat untuk menyaring pesan yang datang. Hal tersebut, berdampak pada pola tingkah laku dan budaya dalam masyarakat. Kebudayaan yang sudah lama ada dan menjadi tolak ukur masyarakat dalam berprilaku kini hampir hilang dan lepas dari perhatian masyarakat. Sehingga terjadi secara berkesinambungan adanya perubahan-perubahan sosial di masyarakat mulai terangkat ke permukaan dan terdapat kecendrungan baru dalam pembentukan watak sesorang melalui sosial media.

Perubahan melalui sosial media yang jelas terlihat adalah berubahnya struktur sosial dan pola budaya dalam suatu masyarakat, perubahan tersebut seperti perubahan sikap, tingkah laku yang tidak menutup kemungkinan bahwa proses perubahan akibat sosial media ini akan melunturkan atau mengurangi derajat bentuk-bentuk atau nial-nilai yang sudah ada dalam masyarakat, yang mengakibatkan masyarakat mulai meninggalkan kebiasaan atau budayanya karena mengganggap kebudayaan itu sudah kuno. Seperti halnya terhadap isu soal hoax, telah menjadi permasalahan isu global dalam masyarakat di tanah air. Penyelesaian terhadap maraknya hoax pemerintah telah melakukan konfirmasi lewat Kominfo, dengan berbagai pihak dari luar, seperti Facebook dan Google. Kerja sama dilakukan untuk menyaring konten dan beragam informasi. Terkait regulasi, peredaran informasi agar tidak "liar" dapat dilakukan sesuai koridor Undang-Undang Nomor 40 Tahun 1999 tentang Pers (UU Pers) bagi media massa. Sanksi bagi penyebar informasi hoax bisa dikenakan hukuman sesuai yang tercantum dalam Undang-Undang Nomor 11 Tahun 2008 tentang Informasi dan Transaksi Elektronik (UU ITE).

Permasalahan tersebut, menjadikan masyarakat memiliki pertimbangan etika dalam memanfaatkan media sosial,". Interaksi di media sosial adalah hal yang tak bisa dicegah dan dibendung. Pembatasan dalam penggunaan media sosial sama saja dengan membatasi masuknya halhal positif. Sebab, media sosial di sisi lain juga membawa banyak dampak positif. Hal serupa diungkapkan oleh pengamat media sosial, Nukman Luthfie sebagai berikut.

Pada era now, masyarakat sulit membedakan informasi yang benar dan salah, hal terpenting adalah meningkatkan literasi media dan literasi media sosial. Sebab, penyebaran informasi hoax juga dapat dilakukan oleh mereka yang terpelajar. "Pengguna mobile phone, ketika ada berita lewat Twitter, Facebook, WhatsApp, hanya lihat judul kemudian disebarkan. Ini fakta, karakter yang menarik dan tidak 
pernah terjadi sebelumnya. Selain kebiasaan berbagi secara cepat, pola baca masyarakat juga berubah total. Jika membaca buku halaman berapa, dan koran alinea berapa, pembaca berita online cenderung membaca secara cepat.

Hal tersebut, menunjukkan bahwa adanya perubahan gaya hidup dan pola tingkah laku masyarakat sehingga menyebabkan terjadinya pergeseran nilai-nilai budaya dalam kehidupan masyarakat. Sosial media mempengaruhi gaya hidup masyarakat untuk menjadi serupa dengan apa yang disajikan oleh sosial media. Sadar atau tidak masyarakat pun masuk kedalamnya bahkan menuntut lebih dari itu. Sosial media secara perlahan-lahan namun efektif membentuk pandangan masyarakat terhadap bagaimana seseorang melihat pribadinya dan bagaimana seseorang seharusnya berhubungan dengan dunia sehari-hari walau sudah melenceng dari tahap perkembangan jiwa maupun normanorma yang berlaku. Buruknya hal tersebut tidak dianggap sebagai suatu kesalahan.

\subsection{Pengaruh Media Sosial Terhadap \\ Kesehatan Jiwa}

Penggunaan sosial media secara berlebihan berdampak buruk pada kesehatan jiwa dan mental. Gagguan kejiwaan dan gangguan mental tanpa disadari oleh pengguna sosial media tersebut. Hasil penelitian para ahli mengungkap bahwa satu dari delapan pengguna sosial media terutama facebook adalah penderita gangguan jiwa dan mental. Ganggua tersebut, berupa pemikiran irasional, yaitu menganggap orang lain lebih ceroboh, bodoh, dan tidak berperilaku seperti yang seharusnya. Rela melakukan sebuah kebohongan hanya untuk menarik simpati termasuk lawan jenis atau teman-teman di sosial media dengan bermacam-macam tujuan. Gangguan kejiwaan tersebut, juga menyebabkan orang pendiam di dunia nyata tiba-tiba menjadi seseorang yang kasar dan sering mencaci maki orang lain melalui akun sosial media ataupun di forum-forum yang diikutinya. Pengaruh buruk media sosial terhadap kesehatan jiwa (gangguan Mental) adalah sebagai berikut.

Pertama, berdampak pada Attention Deficit Hyperactivity Disorde (ADHD), merupakan gangguan perkembangan yang umumnya ditemui pada anak-anak. Gejalanya adalah perasaan selalu gelisah, tidak bisa tenang, serta mudah teralihkan pikiran dan perhatiannya. Sehingga, penderitanya nggak akan bisa fokus dalam belajar atau bekerja.

Kedua, Depresi. merupakan istilah umum untuk menggambarkan perasaan sedih yang mendalam, atau 
tertekan secara berlebihan. Depresi dapat menyebabkan hilangnya minat dan semangat di dalam diri, malas beraktivitas, gangguan pola tidur, bahkan mampu mendorong untuk melakukan bunuh diri.

Ketiga, Obsessive-compulsive Disorder (OCD), merupakan gangguan psikologis yang membuat penderitanya selalu merasa cemas akan berbagai hal secara berlebihan. Bahkan, penderitanya dapat melakukan suatu hal yang sama secara berulang-ulang tanpa alasan yang jelas.

Keempat, Narcissistic Personality Disorder (NPD). Penderita NPD akan menjadi orang yang arogan, egois, dan tidak bisa berempati dengan orang lain. Mereka selalu mengharapkan pujian dan kekaguman dari orang-orang disekitarnya. Mereka jadi sulit menjalin hubungan dengan orang lain dan rentan terancam depresi. Gejala NPD orang suka pamer foto dirinya sendiri dengan berbagai gaya di sosial media.

Kelima, Hypochondriasis, yang merupakan salah satu gangguan psikologis ketika penderitanya merasakan cemas yang berlebihan terhadap kesehatan tubuhnya, atau merasa menderita penyakit serius. Padahal, sebenarnya penyakit tersebut hanya ada di dalam khayalannya.

Keenam, Schizoaffective dan Schizotypal Disorder, merupakan penyakit mental yang membuat penderitanya mengalami halusinasi, pikiran yang membingungkan, depresi, hingga gangguan ingatan. Bahkan penyakit mental ini mendorong potensi bunuh diri, bahkan membunuh orang lain.

Ketujuh, Body Dysmorphic Disorder, yaitu seseorang yang memiliki rasa takut dan cemas yang berlebihan terhadap suatu kelainan pada bagian tubuhnya. Bukan hanya memperhatikan bagian-bagian tubuh, mereka juga tidak dapat berhenti memikirkan penampilannya, dan selalu ingin terlihat sempurna. Jika menemukan kelainan atau kekurangan pada bagian tubuhnya, mereka akan merasa tertekan dan mengalami depresi.

Kedelapan, Voyeurism, diartikan sebagai perilaku suka mengintip. Namun, dalam konteks sosial media, voyeurism merujuk kepada sikap penasaran yang berlebihan terhadap seseorang, sehingga melakukan stalking secara mendalam, hingga benar-benar terobsesi pada orang tersebut secara tidak wajar.

Kesembilan, Addiction, berarti ketagihan. Semakin sering melakukan berbagai aktivitas di media sosial, seseorang akan ketagihan dan ingin melakukannya lagi, secara terusmenerus, dan tanpa henti. Ketagihan ini tentu membuat pola hidup yang normal menjadi berantakan. 
.2.3. Pandangan Antropologi Kesehatan Terhadap Pengaruh Buruk Media Sosial dalam Eksistensi Rumah tangga Hindu

\subsubsection{Penyimpangan Hubungan Sex Pasangan Suami-Istri}

Hubungan seks dianggap surganya bagi pasangan suami-istri, tak jarang membuat seseorang tenggelam dalam kesenangan dunia material melalui media sosial. Hubungan seks merupakan salah satu tujuan hidup manusia setelah kekayaan, akan tetapi untuk mencapai tujuan tersebut harus berlandaskan pada (kebenaran agama, aturan, hukum). Demikian halnya melakukan hubungan badan (bersanggama, hubungan intim) memiliki aturannya sendiri.

Isu terhadap pasangan menikah yang mengalami masalah hubungan seks atau masalah di tempat tidur karena pengaruh media sosial. Faktanya, diperkirakan bahwa satu dari tiga pasangan memiliki kesenjangan hasrat seksual. Hasil penelitian yang dilakukan oleh National Marriage Project di tahun 2011, menunjukkan bahwa pasangan menikah yang bahagia menempatkan seks di posisi atas bersama dengan komunikasi, komitmen, dan kemurahan hati. Pasangan yang mengalami masalah seksual, waktunya untuk berfokus terhadap cara-cara meningkatkan komunikasi, ketertarikan seksual, dan mungkin mencari bantuan dari ahli profesional. Pasangan yang mengalami masalah seksual akan berdampak pada keharmonisan rumahtangga. Masalah seksual merupakan suatu penyakit sebagaimana dinyatakan oleh David Landy yaitu sebagai berikut.

Landy, menyatakan bahwa penyakit diasumsikan dengan kondisi organisme yang merupakan persyaratan serius terhadap adaptif, sebab kalau tidak, akan menyebabkan sakit fisik dan mengalami disfungsi perilaku. Akan tetapi, ini tentu merupakan asumsi yang belum pasti dapat diterima. Ketika asumsi ini diterapkan pada hewan dan manusia, hasilnya adalah tidak ada individu manusia yang benar-benar sehat (Landy, 1977:129). Demikian halnya dengan pencegahan penyakit dan perawatan penyakit juga merupakan bagian dari setiap sistem medis. Untuk penularan suatu penyakit bergantung kepada kebiasaan dan kontak sosial antara anggota masyarakat dan orang asing.

Pernyataan tersebut, sejalan dengan teori Hipocrates (460-377 SM)) tentang keadaan sehat sakit yaitu sebagai berikut.

Konsepsi terhadap sehat tidak hanya menyangkut bebas dari sakit atau penyakit, tetapi juga untuk menikmati seterusnya tanpa terputus-putus keadaan fisik, mental, dan spiritual yang bahagia dan utuh. Konsep keadaan keseimbangan yang benar dan hakiki 
tersebut tidak hanya menyangkut berfungsinya sistem dan organ tubuh manusia dengan baik dan lancar, psikis dan spiritual (jasmani dan rohani) tetapi juga menyangkut keseimbangan hubungan secara dinamis dengan lingkungan yang lebih luas, yakni hubungan harmonis antaranggota keluarga sendiri, tetangga, teman dekat dan anggota masyarakat secara lebih luas, serta antara manusia dan Tuhan.

Pernyataan tersebut, menunjukkan bahwa faktor keseimbangan sistemik didalam tubuh baik fisik, mental, dan spiritual berpengaruh terhadap sehat sakit seseorang. Demikian halnya dengan gangguan seksual terhadap pasangan suami istri merupakan keadaan ketidakseimbangan yang segera ditanggulangi. Sehingga keharmonisan pasangan suami istri dapat terjalin kembali.

Masalah seksual yang dialami setiap pasangan suami istri segera ditanggulangi dengan mengetahui waktu yang tepat dalam melakukan hubungan seks dan tidak melakukan hubungan seks disaat pikiran sedang kacau. Melakukan percakapan tentang masalah seksual bisa menyulitkan dan terasa canggung, apalagi jika merasakan kurangnya ketertarikan seksual di tempat tidur. Hal tersebut, tidak dibicarakan dengan pasangan secara tiba-tiba ketika makan malam di restoran atau sedang bersama teman. Masalah hubungan seksual dibicarakan ketika sedang berdua dan di tempat yang pribadi. Waktu yang baik disaat berdua menjelang tidur atau setelah makan malam bersama di rumah. Memperkuat hubungan seksual antara pasangan yaitu dengan selalu memelihara komunikasi yang terbuka dan jujur. Membicarakan masalah seksual dalam pernikahan akan menunjukkan bahwa salah satu usaha untuk menjadikan seks sebagai prioritas dalam hubungan, dan bukan sesuatu yang jarang dilakukan.

Pasangan suami istri yang melakukan hubungan intim setiap hari tidak hanya memiliki kehidupan yang harmonis dengan pasangan, tapi juga terhindar dari beragam penyakit. Titik klimaks yang dicapai setiap harinya akan membuat seseorang mudah untuk tidur nyenyak dan terhindar dari stres, serta kalori di tubuh akan mudah terbakar. Hal tersebut, dinyatakan dalam Times of India terhadap pasangan suami istri yang melakukan hubungan intim setiap hari akan memberikan sembilan manfaat kesehatan pada tubuh, yaitu sebagai berikut.

Pertama, terhindar dari penyakit jantung. Sebuah studi terbaru mengatakan, pria yang berhubungan seks lebih dari dua kali seminggu akan memiliki risiko lebih rendah terkena serangan jantung, dibandingkan dengan pria yang memiliki hubungan seks 
kurang dari sekali dalam sebulan.

Kedua, Kekebalan tubuh meningkat. Berhubungan seks secara rutin akan membuat tubuh mengeluarkan immuno globin dalam jumlah banyak, antibodi ini bermanfaat untuk melindungi tubuh dari demam dan flu.

Ketiga, terhindar dari stres. Memiliki masalah keluarga atau pekerjaan bukan alasan bagi pasangan suami istri untuk tidak bercinta. Kehidupan seksual yang baik akan membuat pasangan mendapatkan mood yang baik serta rasa bahagia yang tinggi.

Keempat, mengurangi rasa sakit. Tidak diperlukan untuk minum obat penghilang rasa sakit, jika bercinta dapat menyembuhkan dari rasa sakit. Bercinta setiap hari hingga mencapai orgasme akan meredakan rasa sakit yang dirasa. Hal tersebut, merupakan hasil penelitian orgasme sehingga tubuh mengeluarkan hormon oksitosin sebanyak lima kali lipat, dan dapat megurangi rasa sakit.

Kelima, berumur panjang. Pada saat seseorang dalam keadaan orgasme, ada hormon dehydroepiandrosterone yang dilepaskan. Hal tersebut, dapat meningkatkan imunitas, perbaikan jaringan dan membuat kulit tetap sehat. Pria yang memiliki orgasme dua kali dalam seminggu akan memiliki hidup lebih panjang dari mereka yang bercinta sekali dalam beberapa pekan.

Keenam, tingkatkan sirkulasi darah. Detak jantung yang meningkat ketika bercinta dapat menyuplai darah segar ke organ dan sel penting di tubuh. Sedangkan darah yang sudah digunakan akan diolah kembali untuk menghilangkan racun dan penyebab lelah di tubuh.

Ketujuh, kwalitas tidur meningkat. Setelah bercinta pasangan suami istri akan merasakan tubuh yang lebih rileks dan santai. Tentunya hal ini akan membuat tidur menjadi lebih nyenyak. Kwalitas kebugaran tubuh di pagi hari pun akan semakin terjaga.

Kedelapan, tingkatkan kebugaran. Untuk mendapatkan kebugaran dan mengeluarkan keringat cukup dengan bercinta. Bercinta juga dapat membuat pasangan mengeluarkan keringat dan membakar lemak serta menjaga kebugaran tubuh. Seks teratur akan membuat pinggang jadi lebih ramping. Setengah jam bercinta dapat membakar lemak hingga 80 kalori.

Kesembilan, meningkatkan kadar hormon estrogen dan testosteron. Pada pria, testoteron tidak hanya untuk membesarkan penis, namun juga untuk meningkatkan kekuatan tulang dan otot serta menjaga kesehatan jantung dan menstabilkan kolesterol. Begitu juga dengan wanita, hormon estrogen yang meningkat akan membuat mereka terhindar dari risiko penyakit jantung dan memberikan aroma tubuh yang baik. 


\subsubsection{Terapi Seks}

Seorang ahli penyembuhan klinik pengobatan keluhan seks lebih banyak membantu masalah kehidupan seks dan problematikanya baik bagi pasangan suami istri maupun individu yang mengalami masalah dan keluhan dalam kehidupan seksualnya. Mare Simone sudah melakukan pengobatan terapi seks ini lebih dari 23 tahun dan lebih dari 10.000 klien sudah menjadi pasiennya baik pria maupun wanita. Lebih dari itu seperti dikutip ruanghati.com dari Majalah The Sun Inggris, Mare juga sudah melakukan hubungan seks dengan 1500 pria pasiennya yang menurutnya lebih merupakan sebuah proses terapi bukan seperti hubungan seks antara pria dengan wanita pekerja seks.

Mare bersikeras bahwa hubungan seks yang dilakukan tersebut benar benar bersifat penyembuhan bukan pelacuran. Selama ini Mare mendapatkan banyak pasien yang membutuhkan konseling problematika seks bahkan hingga problem kesuburan dalam masalah suami istri. Menurutnya, tugas adalah memberikan pelayanan yang memuaskan pada klien dan pelanggan. Pasien yang datang dari berbagai kalangan dan profesi serta strata ekonomi yang beragam. Dinyatakan pula, bahwa kebanyakan pria mendapatkan masalah ereksi dan ejakulasi dini juga masalah tidak bisa memberikan kebahagiaan seks dan memuaskan istri. Salah satu trik penyembuhannya yaitu dengan duduk berdua dengan pasien bugil atau tanpa sehelai benangpun di depan kaca cermin, kebanyakan pria tidak percaya diri melihat tubuhnya sendiri dan sesi ini dimaksudkannya untuk membangun rasa percaya diri bada pasien tersebut.

Terapi yang dilakukan dengan berkomonikasi dengan pasien. Pasien diajak ngobrol lalu sambil dibelai dan diberikan sentuhan sentuhan pada titik titik tertentu dengan pemijatan khusus, agar pasien bisa merasa lebih rileks. Profesi yang dijalani Mare saat ini tidak terlepas dari perjalanan hidupnya masa lalu, dimana pada usia 19 tahun Mare diperkosa oleh teman laki-lakinya saat pulang pesta tengah malam, dan pemerkosaan itu memberikan pengalaman pahit serta trauma yang berkepanjangan bahkan hingga Mare menikah dengan seorang pria bernama Victor pun dirinya belum bisa merasakan hubungan seks yang normal karena masih dibayangi kejadian pemerkosaan padanya dimasa lalu, hal inilah yang membuat Mare ingin lebih tau dan mencari solusinya. Namun akhirnya Victor dan Mare bercerai karena hal buruk itu.

$$
\text { Hingga suatu hari Mare }
$$
menemukan beberapa tantra seks Hindu dan surrogacy seksual yang lebih bersifat penyembuhan dan terapi seks 
secara kejiwaan bukan fisik diantaranya upaya menumbuhkan rasa percaya diri dalam seksualitas. Salah satu lagi adalah agar para pasiennya bisa merasa melakukan seks tanpa merasa jijik dan kotor serta bersalah.

Saat ini Mare lebih banyak melakukan praktek di Amerika dimana pasien harus antri untuk mendapatkan penyembuhan darinya, perharinya bisa diselesaikan 4-5 orang denga biaya $\mathrm{Rp}$ 1,5 juta persesinya. Yang juga terdengar aneh oleh kita iyalah salah satu yang dilakukan dalam penyembuhan terapi ini Mare juga pernah melakukan hubungan seks dengan seorang pria di hadapan istrinya sebagai salah satu terapi penyembuhan dalam fungsi sensitifitas pasien pada pasangannya.

Mare pun begitu mencintai profesinya dan tidak peduli dengan apa yang orang katakan tentang yang telah diperbuatnya "I am a sexual healer and so proud and happy that I found my dream job."

Solusi bagi pasangan suami istri yang mengalami gangguan seksualitas yaitu sebagai berikut.

Pertama, bersikaplah proaktif dan mulailah percakapan dan menyadari pentingnya memiliki hubungan yang intim dalam hubungan asmara, khususnya dalam pernikahan.

Kedua, fokuslah pada cara berdua dalam memenuhi kebutuhan satu sama lain. Komunikasi dengan pasangan untuk menyadari bahwa adanya ketidak bahagiaan dengan kehidupan percintaan dan berusaha melakukan sesuatu untuk mengatasinya. Jika pasangan menanggapinya jangan berkecil hati. Sebaliknya, tanyakan kepada pasangan bagaimana caranya agar bisa memenuhi kebutuhannya, yaitu kebutuhan seksual, dan begitu pula sebaliknya. Bicarakan bahwa apa yang dirasakan pasangan merupakan kurangnya ketertarikan dalam hubungan seksual dan apa yang dirasakan adalah kurangnya ketertarikan seksual.

Ketiga, sering kali pasangan dengan masalah seksual juga memiliki masalah emosional yang belum ada solusinya dan berhubungan dengan hubungan asmara. Mengalami kurangnya ketertarikan seksual karena kebosanan di tempat tidur, gairah seks yang rendah (untuk pasangan), kesan negatif terhadap tubuh, kelelahan karena stres dalam kehidupan, atau kurangnya hubungan secara mental dan emosional.

Keempat, melakukan bekerja sama untuk mengidentifikasi masalah yang menyebabkan kurangnya ketertarikan seksual. Memang sulit untuk membicarakan masalah seputar seks. Namun sebagai mitra, pasangan, wajib untuk saling jujur dan mengungkapkan masalah seputar keintiman dan seks.

Kelima, dengan mendengarkan satu sama lain. Jangan menyela 
pasangan ketika ia sedang mengungkapkan perasaan atau masalah. Berfokuslah untuk mendengarkan sebelum menanggapi atau berbicara.

Keenam, apabila pasangan mengungkapkan perasaan bosan di tempat tidur, pikirkan cara untuk menambah variasi dalam rutinitas seks yang biasa-biasa saja. Pasangan mungkin merasa lelah dengan rutinitas kerja sehari-hari atau merasakan kesan negatif terhadap tubuhnya. Diskusikan solusi untuk masalah ini, seperti mengurangi jam kerja di kantor, berlibur berdua saja, atau melakukan olahraga bersama.

Ketujuh, menciptakan suasana hati. Hal ini bisa berupa membuat malam romantis di rumah, dilengkapi lilin, pijatan, dan taburan kelopak mawar. Atau, bisa berarti membayangkan situasi di masa lalu saat berdua bergairah dan merasa terhubung secara seksual. Pada momen di masa lalu tersebut, dengan meluangkan lebih banyak waktu untuk melakukan pemanasan, melakukan hubungan seks dalam berbagai posisi, dalam waktu yang berbeda-beda, atau di tempat yang berbeda-beda dan ciptakan situasi yang membuat berdua bergairah seperti di masa lalu dan bisa bergairah lagi sekarang.

Kedelapan, dengan melakukan eksperimen untuk menciptakan hal baru. Kebosanan adalah salah satu penyebab utama masalah seksual di antara pasangan yang menikah, apalagi jika Anda berdua cenderung berada dalam rutinitas atau melakukan posisi biasa di tempat tidur. Diskusikan posisi atau hal yang lebih menantang dan bersedialah untuk mencoba hal-hal yang tidak pernah dilakukan sebelumnya untuk mengetahui apakah berdua menikmatinya. Jangan takut untuk melakukan eksperimen bersama.

Kesembilan, dengan membuat jadwal kencan seks. Meskipun membuat jadwal berhubungan seks tepat waktu tampak formal, hal ini bisa meyakinkannya kembali kalau Anda berdua akan menjadikan seks sebagai prioritas. Cobalah membuat jadwal kencan seks dalam waktu singkat selama enam bulan. Berfokuslah untuk menjalankan kencan berdua dengan cara yang intim, bahkan jika Anda tidak sedang ingin berhubungan seks. Hal ini akan membantu Anda mengatur waktu saat sedang intim, dan bukan mencoba menyesuaikan keintiman ke dalam jadwal.

Kesepuluh, dengan melakukan pemeriksaan medis. Buatlah jadwal pertemuan dengan dokter keluarga dengan mengesampingkan masalah fisik yang mungkin menyebabkan masalah seksual. Cari tahu apakah ada obat yang sedang diminum atau kondisi medis yang menjadi penyebabnya. Menanyakan kepada dokter tentang pengobatan yang mungkin dilakukan 
jika Anda mengalami penurunan gairah seks atau masalah seksual lainnya, seperti impotensi. Dokter akan menyarankan pengobatan atau perubahan pola makan yang harus dilakukan. Disamping itu pula, penting membuat jadwal pertemuan dengan seksolog. Seksolog bertugas untuk membantu pasangan atau individu yang memiliki masalah seksual.

\subsubsection{Hubungan Sex Pasangan Suami- Istri dalam pandangan Hindu}

Terdapat berbagai penjelasan kitab suci weda mengenai tata cara berhubungan seks yang benar. Masyarakat kebanyakan beranggapan bahwa bersanggama dapat dilakukan kapan saja tanpa memperdulikan waktu terlarang untuk bersanggama. Secara alami, gairah seksual seseorang bangkit ketika malam hari, sehingga bersenggama selalu dilakukan pada malam hari. Akan tetapi, ada beberapa orang yang melakukan hubungan seksual pada siang hari akibat tidak mampu mengendalikan nafsu seksnya. Sejatinya, agama tidak membenarkan seseorang bersenggama pada siang hari, ketika matahari memancarkan sinarnya.

Dalam agama Hindu, ada dua aliran pemikiran mengenai seks yang saling berlawanan. Aliran pemikiran pertama memandang seks secara negatif dipimpin oleh Bhagawan Wararucci dengan bukunya Sarasamuccaya. Aliran pemikiran kedua memandang seks secara positif dipimpin oleh Bhagawan Vatsyayana dengan bukunya Kama Sutra.

Kitab Manawa Dharmasastra mengatur kesucian dalam berhubungan seks. Karenanya seks di luar nikah dianggap dosa. Hubungan seks dalam Hindu tidak semata-mata untuk kesenangan tetapi untuk memperoleh keturunan. Hubungan seks antara suami istri dalam agama Hindu, dilakukan secara sakral yang dimulai dengan membersihkan badan/mandi, kemudian sembahyang memohon restu dewa-dewi Smara Ratih. Larangan dalam melakukan hubungan sex terhadap seseorang yang dalam keadaan sedang marah, mabuk, tidak sadar, sedih, takut, terlalu senang, dan wanita sedang haid.

Dalam agama Hindu, seks tidak boleh dilakukan pada waktu fajar (siang kangin), tengah hari (bajeg surya), menjelang matahari terbenam (sandyakala), purnama dan hari raya. Selain itu agama Hindu juga melarang melakukan hubungan seks dengan meniru gaya binatang. Demikian halnya di dalam kama sutra telah disebutkan bahwa berhubungan sex yang dilakukan dengan rasa sayang yang telah terikat tali perkawinan, maka akan lahir anak-anak dengan budi pekerti baik yang taat kepada orang tua, rajin sembahyang, pintar, sehat, pandai bergaul dan hidupnya sukses. Sedangkan hubungan 
seks yang dilakukan secara menyimpang, maka anak yang lahir disebut anak "dia-diu" yang biasanya akan bandel, suka menyakiti hati orang tua, bodoh, jahat, banyak musuh, hidupnya sulit dan sering sakit-sakitan.

Keharmonisan rumah tangga mempunyai beberapa faktor yang mempengaruhi. Saling mencintai, fisik kedua belah fihak, material, pendidikan, dan agama merupakan faktor yang mempengaruhi dalam keharmonisan. Namun yang paling penting adalah kedewasaan diri dari kedua pasangan. Jika kedua pasangan telah memiliki kedewasaan untuk menjalankan perannya dalam rumah tangga maka didalam keluarga tersebut akan terjadi kesinambungan dan keseimbangan yang saling mengisi satu sama lain sehingga tercipta kesejahteraan dalam rumah tangganya (Hasan Basri, Keluarga Sakinah Tinjauan Psikologi dan Agama, (Yogyakarta; Pustaka pelajar, 2002), 57).

Hindu memandang bahwa hubungan seksual pasangan suami istri adalah sakral dan dalam berhubungan intim memiliki aturan sebagaimana telah disebutkan dalam kitab Manawa Dharmasastra yaitu sebagai berikut.

1. Membersihkan badan atau mandi terlebih dahulu.

2. Sembahyang mohon restu DewaDewi Smara Ratih.

3. Hubungan seks jangan dilakukan ketika sedang marah, mabuk, tidak sadar, sedih, takut, terlalu senang. Ketika wanita sedang haid, waktu yang tidak tepat: siang kangin (fajar), bajeg surya (tengah hari), sandyakala (menjelang matahari terbenam), purnama, tilem, rerainan (hari raya), odalan, sedang melaksanakan upacara panca yadnya. jangan meniru "gaya binatang", yang disebut "alangkahi akasa" (melangkahi angkasa)dalam berhubungan seks selalu berbentuk "lingga-yoni".

4. Berhubungan intim dengan diiringi musik, tapi pilihlah musik yang tenang, misalnya ada gambelan "semare pegulingan" artinya asmara di tempat tidur. Semare pegulingan merupakan jenis gambelan khas yang ditabuh di Puri-Puri saat sang Raja sedang berhubuungan intim dengan Permaisurinya.

Kitab Manawa Dharmasastra mengatur kesucian dalam berhubungan seks. Karenanya seks di luar nikah dianggap dosa. Hubungan seks dalam Hindu tidak semata-mata untuk kesenangan tetapi untuk memperoleh keturunan.

Hubungan seks antara suami istri dalam agama Hindu, dilakukan secara sakral yang dimulai dengan membersihkan badan/mandi, kemudian sembahyang memohon restu dewa-dewi Smara Ratih. Bagi mereka yang sedang marah, mabuk, tidak sadar, sedih, takut, 
terlalu senang, dan wanita sedang haid dilarang berhubungan seks.

Dalam agama Hindu, seks tidak boleh dilakukan pada waktu fajar (siang kangin), tengah hari (bajeg surya), menjelang matahari terbenam (sandyakala), purnama dan hari raya. Selain itu agama Hindu juga melarang melakukan hubungan seks dengan meniru gaya binatang.

Bahkan ada keyakinan di kalangan umat Hindu bahwa bila hubungan seks yang dilakukan sesuai dengan swadharma kama sutra, maka akan lahir anak-anak dengan budi pekerti baik yang taat kepada orang tua, rajin sembahyang, pintar, sehat, pandai bergaul dan hidupnya sukses. Namun jika hubungan seks dilakukan secara menyimpang, maka anak yang lahir disebut anak "dia-diu" yang biasanya akan bandel, suka menyakiti hati orang tua, bodoh, jahat, banyak musuh, hidupnya sulit dan sering sakit-sakitan. [Berbagai Sumber/A1/W1]

\subsection{Eksistensi Keharmonisan Rumah Tangga Hindu}

Keharmonisan rumah tangga secara terminologi berasal dari kata harmonis yang berarti serasi, selaras. Titik berat dari Keharmonisan adalah kedaan selaras atau serasi, keharmonisan bertujuan untuk mencapai keselarasan dan keserasian, dalam kehidupan rumah tangga perlu menjaga kedua hal tersebut untuk mencapai keharmonisan rumah tangga (Tim Penyusun, 299 :1989).

Keluarga yang harmonis dan berkualitas yaitu keluarga yang rukun berbahagia, tertib, disiplin, saling menghargai, penuh pemaaf, tolong menolong dalam kebajikan, memiliki etos kerja yang baik, bertetangga dengan saling menghormati, taat mengerjakan ibadah, berbakti pada yang lebih tua, mencintai ilmu pengetahuan dan memanfaatkan waktu luang dengan hal yang positif dan mampu memenuhi dasar keluarga (Hasan Basri, 111 : 1996).

Keluarga harmonis hanya akan tercipta kalau kebahagiaan salah satu anggota berkaitan dengan kebahagiaan anggota-anggota keluarga lainnya. Secara psikologis dapat berarti dua hal:

1. Tercapainya keinginankeinginan, cita-cita dan harapanharapan dari semua anggota keluarga.

2. konflik hanya terjadi dalam pribadi masing-masing maupun antar pribadi (Sarlito, : 2-1982).

Keluarga harmonis merupakan keluarga yang penuh dengan ketenangan, ketentraman, kasih sayang, keturunan dan kelangsungan generasi masyarakat, belas-kasih dan pengorbanan, saling melengkapi dan $\mathrm{m}$ enyempurnakan, serta saling membantu dan bekerja sama (Ali, 14 : 
2002). Keluarga yang harmonis atau keluarga bahagia adalah apabila kedua pasangan tersebut saling menghormati, saling menerima, saling menghargai, saling mempercayai, dan saling mencintai (Zakiah, 9: 1975).

Gunarsah berpendapat bahwa keluarga bahagia adalah apabila seluaruh anggota keluarga merasa bahagia yang ditandai oleh berkurangnya rasa ketegangan, kekecewaan, dan puas terhadap seluruh keadaan dan keberadaan dirinya (eksistensi dan aktualisasi diri) yang meliputi aspek fisik, mental, emosi, dan sosial. Sebaliknya keluarga yang tidak bahagia adalah apabila dalam keluarganya ada salah satu atau beberapa anggota keluarga yang diliputi oleh ketegangan, kekecewaan, dan tidak pernah merasa puas dengan keadaan dan keberadaan dirinya terganggu atau terhambat (Singgih dan Yulia, 51 : 1991).

Suami istri bahagia menuut Hurlock adalah suami istri yang memperoleh kebahagiaan bersama dan membuahkan keputusan yang diperoleh dari peran yang mereka mainkan bersama, mempunyai cinta yang matang dan mantap satu sama lainnya, dan dapat melakukan penyesuaian seksual dengan baik, serta dapat menerima peran sebagai orang tua (Hurlock, 299 : 1999).

Pandangan tersebut, menunjukkan bahwa keharmonisan rumah tangga adalah terciptanya keadaan yang sinergis diantara anggotanya yang di dasarkan pada cinta kasih, dan mampu mengelola kehidupan dengan penuh keseimbangan (fisik, mental, emosional dan spiritual) baik dalam tubuh keluarga maupun hubungannya dengan yang lain, sehingga para anggotanya merasa tentram di dalamnya dan menjalankan peran-perannya dengan penuh kematangan sikap, serta dapat melalui kehidupan dengan penuh keefektifan dan kepuasan batin.

Keluarga sejahtera merupakan tujuan penting, maka untuk menciptakannya perlu diperhatian faktor berikut (Singgih dan Yulia, 42-44 : 1991). Menaruh hati pada seluruh anggota keluarga sebagai dasar utama hubungan baik antar anggota keluarga terpenting adalah perhatian. Baik pada perkembangan keluarga dengan memperhatikan peristiwa dalam keluarga, dan mencari sebab akibat permasalahan, juga terhadap perubahan pada setiap anggotanya. Perhatian tersebut adalah sebagai berikut.

1. Pengetahuan. Perlunya menambah pengetahuan tanpa henti-hentinya untuk memperluas wawasan sangat dibutuhkan dalam menjalani kehidupan keluarga. Sangat perlu untuk mengetahui anggota keluarganya, yaitu setiap 
perubahan dalam keluarga, dan perubahan dalam anggota keluargannya, agar kejadian yang kurang dinginkan kelak dapat diantisipasi.

2. Pengenalan terhadap semua anggota keluarga. Hal ini berarti pengenalan terhadap diri sendiri dan Pengenalan diri sendiri yang baik penting untuk memupuk pengertian-pengertian.

3. Bila pengenalan diri sendiri telah tercapai maka akan lebih mudah menyoroti semua kejadian dan peristiwa yang terjadi dalam keluarga. Masalah akan lebih mudah diatasi, karena banyaknya latar belakang lebih cepat terungkap dan teratasi, pengertian yang berkembang akibat pengetahuan tadi akan mengurangi kemelut dalam keluarga.

4. Sikap menerima. Langkah lanjutan dari sikap pengertian adalah sikap menerima, yang berarti dengan segala kelemahan, kekurangan, dan kelebihannya, ia seharusnya tetap mendapatkan tempat dalam keluarga. Sikap ini akan menghasilakan suasana positif dan berkembangnya kehangatan yang melandasi tumbuh suburnya potensi dan minat dari anggota kleuarga.
5. Peningkatan usaha. Setelah menerima keluarga apa adanya maka perlu meningkatkan usaha, dengan mengembangkan setiap dari aspek keluarganya secara optimal, hal ini disesuaikan dengan kemampuan masing-masing, tujuannya yaitu agar tercipta perubahanperubahan dan menghilangkan keadaan kebosanan dan kestatisan.

6. Penyesuaian harus selalu mengikuti setiap perubahan baik dari pihak orang tua maupun anak.

Keluarga harmonis atau keluarga bahagia adalah apabila dalam kehidupannya telah memperlihatkan faktor-faktor sebagai berikut.

1. Faktor kesejahteraan jiwa. Yaitu redahnya frekwensi pertengkaran dan percekcokan di rumah, saling mengasihi, saling membutuhkan, saling tolong-menolong antar sesama keluarga, kepuasan dalam pekerjaan dan pelajaran masingmasing dan sebagainya yang merupakan indikator-indikator dari adanya jiwa yang bahagia, sejahtera dan sehat.

2. Faktor kesejahteraan fisik. Seringnya anggota keluarga yang sakit, banyak pengeluaran untuk kedokter, untuk obat- 
obatan, dan rumah sakit tentu akan mengurangi dan menghambat tercapainya kesejahteraan keluarga.

3. Faktor perimbangan antara pengeluaran dan pendapatan keluarga. Kemampuan keluarga dalam merencanakan hidupnya dapat menyeimbangkan pemasukan dan pengeluaran dalam keluarga. Misalnya; Banyak keluarga yang kaya namun mengeluh kekurangan (Sarlito, 79: 1982).

Kunci utama keharmonisan sebenarnya terletak pada kesepahaman hidup suami dan isteri. Karena kecilnya kesepahaman dan usaha untuk saling memahami. Hal tersebut, akan membuat keluarga menjadi rapuh. Makin banyak perbedaan antara kedua belah pihak maka makin besar tuntutan pengorbanan dari kedua belah pihak. Jika salah satunya tidak mau berkorban maka pihak satunya harus banyak berkorban. Jika pengorbanan tersebut telah malampaui batas atau kerelaannya maka keluarga tersebut terancam. Maka pahamilah keadaan pasangan, baik kelebihan maupun kekurangan untuk mengerti sebagai landasan dalam menjalani kehidupan berkeluarga. Rencana kehidupan yang dilakukan kedua belah pihak merupakan faktor yang sangat berpengaruh karena dengan perencanaan ini keluarga bisa mengantisipasi hal yang akan datang dan terjadi saling membantu untuk misi keluarga (Ibid, hal 79-82).

Membina keharmonisan rumah tangga akan berhasil tergantung dari penyesuaian antara kedua belah pihak dan bagaimana mengatasi kesulitankesulitan yang muncul sebagai mana halnya sebagai berikut.

1. Menghadapi kenyataan. Suami isteri perlu menghadapi kenyataan hidup dari semua yang terungkap dan tersingkap sebagai suatu tim, dan menanggulanginya dengan bijaksana untuk menyelesaikan masalah.

2. Penyesuaian timbal balik. Perlu usaha terus menerus dengan saling memerhatikan, saling mengungkapkan cinta dengan tulus, menunjukkan pengertian, penghargaan dan salaing memberi dukungan, semangat. Kesemuanya berperan penting dalam memupuk hubungan yang baik, termasuk dalam hubungan yang paling intim antara suami dan isteri yakni seks.

3. Latar belakang suasana yang baik. Untuk menciptakan suasana yang baik, dilatar 
belakangi oleh pikiran-pikiran, perbuatan dan tindakan yang penuh kasih sayang. Maka macam-macam perasaan jengkel, kecewa, tidak adil yang bisa menimbulkan prasangka, curiga yang mewarnai suasana hubungan suami-isteri dan mempengaruhi hubungan intim mereka harus di jauhi.

Kesibukan atau kegiatan yang berlebihan pada suami atau isteri, sehingga tersita waktu untuk memupuk dan memelihara suasana baik, akrab akan mengganggu hubungan intim. Karena itu diperlukan usaha untuk menciptakan suasana dengan memperhatikan: Masing-masing tidak kehilangan individualitas, azaz berbagi bersama diterapkan seluas mungkin, berusaha menjauhkan dan menghentikan kebiasaan atau cara yang tidak disenangi suami atau istri, setiap tindakan dan keputusan penting harus dibahas terlebih dahulu untuk memelihara kepercayaan dan kerjasama antar pasangan, setiap pasangan hendaknya menambah kebahagiaan pasangannya. Bertambahnya usia maka bertambah pula kemampuan menghadapi masalah, namun masalah yang muncul semakin baru maka hubungan perlu dijaga agar komunikasi tidak terputus dan harmonis (Singgih dan Yulia, 202-203 : 1991).
Menurut Mazhariri Husain untuk mencapai kebahagiaan dan keharmonisan dalam rumah tangga harus diberlakukan cinta kasih didalamnya. Ambillah butiran cinta kasih dan apa yang dianugerahkan Tuhan dan rasa cinta kasih dalam kehidupan rumah tangga. Anggota keluarga terutama suami istri harus menjaga dari hal yang membuat hilangnya cinta kasih tersebut. Adapun faktor yang menyebabkan hilangnya cinta kasih adalah sebagai berikut.

1. Watak yang keras. Hilangnya cerminan cinta kasih dalam keluarga merupakan akibat dalam rumah tangga berwatak keras. Anggota keluarga berselisih, egois, kurang dapat mengontrol perbuatan, dan ucapannya. Ikatan cinta kasih ini jangan sampai berangsur-angsur hilang, cinta kasih hendaknya harus tetap terjaga dan tidak berubah menjadi kebencian dan kebosanan, pasangan dan keluarga menjadi terhina. Jagalah diri dari watak yang keras untuk menjaga keharmonisan dalam rumah tangga.

2. Perbuatan aniaya. Perbuatan aniaya bermakna luas, mulai dari perbuatan, sikap, maupun katakata. Hindarilah perbuatan 
menganiaya orang lain bahkan keluarga. Caranya dengan menjaga adap atau tatakrama. Perlakukan orang lain dan keluarga dengan penuh perhatian dan menjaga dari perbuatan aniaya untuk menciptakan iklim yang harmonis.

3. Ucapan buruk. Lidah merupakan senjata yang paling tajam dari pda pedang, karena dengannya manusia dapat merasa hancur dan terhina. Akibat dari ketajaman lidah dapat membekas dalam hati pasangan dan anggota keluarga, sehingga ia merasa kurang aman dan tentram dalam keluarganya.dan apabila ini terus berlanjut maka akan memberikan efek berpudarnya kecintaan dan keharmonisan dalam rumah tangga bersangkutan (Husain, 165-174: 2004).

Menurut Basri keharmonisan rumah tangga mempunyai beberapa faktor yang mempengaruhi. Saling mencintai, fisik kedua belah pihak, material, pendidikan, dan agama merupakan faktor yang mempengaruhi dalam keharmonisan. Namun yang paling penting adalah kedewasaan diri dari kedua pasangan. Jika kedua pasangan telah memiliki kedewasaan untuk menjalankan perannya dalam rumah tangga maka didalam keluarga tersebut akan terjadi kesinambungan dan keseimbangan yang saling mengisi satu sama lain sehingga tercipta kesejahteraan dalam rumah tangganya (Hasan, 5-7 : 2002).

Keluarga akan mencapai taraf keharmonisan apabila tidak hanya didasarkan pada faktor biologis semata, namun aspek kasih sayang (afeksional) harus berlaku didalamnya sebagai pilar utama stabilitas suatau perkawinan. Matriks organisasi keluarga (bio-psikososial-spiritual) haruslah di seimbangkan dengan menjaga tali pengikat didalamnya yaitu tali keharmonisan yang berdasarkan afeksional (Dadang, 770-803).

\section{Simpulan}

Perubahan melalui sosial media yang jelas terlihat adalah berubahnya struktur sosial dan pola budaya dalam suatu masyarakat, perubahan tersebut seperti perubahan sikap, tingkah laku yang tidak menutup kemungkinan bahwa proses perubahan akibat sosial media ini akan melunturkan atau mengurangi derajat bentuk-bentuk atau nial-nilai yang sudah ada dalam masyarakat, yang mengakibatkan masyarakat mulai meninggalkan kebiasaan atau budayanya karena mengganggap kebudayaan itu sudah kuno 
Jurnal Penerangan Agama Hindu Vol. 16 No. 2, 2018 


\section{Daftar Pustaka}

Arniati, Ida Ayu Komang. 2008. Pandangan Gender Pada Smerti Dalam Perkembangan Modern. Surabaya: Paramita.

Hasan Basri, Keluarga Sakinah Tinjauan Psikologi dan Agama, (Yogyakarta; Pustaka pelajar, 2002).

Husain Mazhari, Membangun Surga Dalam Rumah Tangga, (Bogor: Cahaya,2004) Singgih D. Gunarsa. dan Yulia Singgih D. Gunarsa. Psikologi untuk Keluarga, (Jakarta: Gunung Mulia. 1986)

Hurlock, EB. Psikologi Perkembangan, Suatu Pendekatan Sepanjang Rentang

Kehidupan,. (Jakarta:Erlangga, 1999) Zakiah Dradjat, Ketenangan dan Kebahagiaan Dalam Keluarga, (Jakarta: Bulan Bintang, 1975)

Ali Qaimi, Menggapai Langit

Masadenpan Anak,(Bogor: Cahaya,

2002)

Tim Penyusun Kamus, Kamus Besar Bahasa Indonesia, (Jakarta: Departemen Pendidikan dan Kebudayaan,1989) Sumber Internet: Http://Paduarsana.com/2012/12/17/kes etaraangender-dalam-hindu/ Http://Suwerta86.blogspot.in/2013/11/g e n d e r - m e n u r u t - p e r s p e k t i f - hindu.html? $\mathrm{m}=1$

Http://id.m.wikipedia.org/wik/gender $\urcorner$ _(sosial)

https://www.psychologytoday.com/blog 
/divorce-busting/201001/11-tips-the- spouse-lower 